University of Nebraska - Lincoln

DigitalCommons@University of Nebraska - Lincoln

Spring 2003

\title{
Truth in Timbre: Morrison's Extension of Slave Narrative Song in Beloved
}

Peter J. Capuano

University of Nebraska - Lincoln, pcapuano2@unl.edu

Follow this and additional works at: https://digitalcommons.unl.edu/englishfacpubs

Part of the English Language and Literature Commons

Capuano, Peter J., "Truth in Timbre: Morrison's Extension of Slave Narrative Song in Beloved" (2003). Faculty Publications -- Department of English. 87.

https://digitalcommons.unl.edu/englishfacpubs/87

This Article is brought to you for free and open access by the English, Department of at DigitalCommons@University of Nebraska - Lincoln. It has been accepted for inclusion in Faculty Publications -- Department of English by an authorized administrator of DigitalCommons@University of Nebraska - Lincoln. 


\section{Truth in Timbre: Morrison's Extension of Slave Narrative Song in Beloved}

\begin{abstract}
His voice was faint. A rustle of leaves. Then Reb lifted his head and began to croon in a tongue incomprehensible to me. Another mourner began to sing. Then another. The sound swelled, expanded, ate space, filled the woods like a splash of wind, blended with the air, turned and touched off, one by one, the different voices of the others, then Reb sang louder-or, better, bellowed like a steer. Abruptly, they stopped, my own face was hot and thick, the tears flew back into my nose when I sniffled and burned my throat. It was then, as Reb drove home the first nail to seal his son's casket, as I felt the sound of metal ring on metal in the deepest coils of my ears, that a voice behind me, toadlike, said:

"At least he was spared the mines, eh, Andrew?" (Charles Johnson, Oxherding Tale)
\end{abstract}

$\mathrm{n}$ her 1987 novel Beloved, Toni Morrison acknowledges and even borrows from Frederick Douglass's 1845 Narrative, but she also makes a resolute break from its rhetorical and political objectives. Historical differences between the audiences of Douglass and Morrison account for a large part of their contrasting styles, particularly in their treatment of slave song. Since Douglass composed his Narrative as a fugitive slave in the early 1840 s, he was aware of his principally white audience and also of his precarious task of presenting an attack not on white America, but on the institution of slavery itself. Douglass's judicious decision to report the bleakness of slavery with austerity of tone allows him to present this attack successfully. He relies heavily on factual evidence, rather than on the tremendously emotional slave songs, to present the most appalling scenes of brutality endured by the slaves in his narrative.

This shrewd emphasis on the factual enables Douglass to navigate between the specific facts and the general nature of slavery in a way that informs rather than offends his audience. In 1845 Douglass could not afford to focus repeatedly on the "ineffable sadness" of slave songs or on the songs' reflection of "souls boiling over with the bitterest anguish," even though he reports early in the Narrative that "every tone [is] a testimony against slavery" (58). As readers, we learn the importance of slave song at the outset, but we learn far more about the exact number of Colonel Lloyd's slaves, horses, and plantation acreage throughout the remainder of the narrative. We come to know the exact assignments involved in Edward Covey's wheat-fanning operation with a precision that leaves us unsatisfied with the important but brief description of the songs reverberating through the pinewoods of the Great House Farm at the outset of the narrative. Despite this, Douglass's task of uncovering the truth of slavery's brutality without mitigating that truth with indignant protestations has proven to be at once inhibiting and fecund. The aware-
Peter J. Capuano is a Presidential Fellow in the University of Virginia's doctoral program for English Language and Literature. His research concentration is the nineteenth-century novel. 
ness of this predicament limits his treatment of slave song in the 1845 Narrative, but it also creates a colossal paradigm of song's importance for many contemporary authors such as Toni Morrison and Charles Johnson, who explore similar topics.

Morrison's Beloved responds deliberately and exhaustively to the description of slave song that appears at the outset of Douglass's 1845 Narrative. The fact that Morrison is not inhibited by the pressing need to abolish slavery allows her to explore the specificity of the slave songs to a degree that Douglass simply could not risk in 1845 . The essential goal of Douglass's Narrative in 1845 was to inform what William Lloyd Garrison dubbed a "stubbornly incredulous" white audience of slavery's politically sanctioned barbarity (40). Since Morrison is not inhibited by the socio-political exigencies taken on by Douglass, she is free to focus more on song as a point of access into the reverberating effects of slavery's horrors - the same horrors that Douglass relates to his readers with a conspicuous deficit of emotion. The project of Morrison's novel is to register and index the vital relationship between the "personhood" of African Americans and the specific songs of former slaves. This is to say that the original description of slave song in Douglass, looming in the background of Morrison's novel, shapes her handling of music and song, her insistence on its signal importance as an indicator of human status in Beloved.

Morrison's consistent but subtle use of song takes the reader beyond the horrifying facts of Douglass's narrative and into the more profoundly emotional turmoil of a post-emancipation community. Morrison reverses the traditional slave narrative format and expands the scope of the reader's comprehension by investigating a crime committed by the oppressed rather than by the oppressor. Through her exploration of the black experience within slavery and beyond, Morrison shows how song defines and affirms slave "personhood" in a world where slave humanity is constantly challenged and denied. Morrison's treatment of song in Beloved provides the reader with a testimony that is significantly different from the testimonies set forth in the slave narratives. Morrison's testimony does not end with the establishment of slavery's barbarity; it chronicles her characters' endurance and ability to survive during and after these periods of physical brutality and psychological abuse. The principal characters of the novel-Sethe, Paul D, and Sixo-all associate song with their humanity and use it as a shield against indignity and despair. In this way, Morrison relies on the rubric of the "sorrow songs" from Frederick Douglass's 1845 Narrative in Beloved to challenge a contemporary audience to recognize slave humanity beyond the simple (but no less important) acknowledgment of slavery's brutality.

Often in Beloved, when characters cannot read or write or even talk about the brutality they experience as slaves, they sing to affirm their participation in life and defend their status as human beings. Song offers slaves the opportunity to express their personal testimonies while remaining within the framework of their larger cultural experiences-all without actually speaking of their shame and trauma. Although Nellie McKay does not specifically identify song as a response to the silencing of slave stories in the introduction to her Beloved casebook, she acknowledges the need for an alternate slave "voice:" "So grotesque were many [slave] experiences, and so vulnerable did they feel, that for them the act of remembering was risky, shameful, and dangerous" (10). Song fulfills the need for what McKay calls an "alternate voice." The slaves of Beloved defend their personhood and revive their endurance when it is challenged and violated by "mossy teeth," numerical measurements, and leg irons. For these reasons, it is fitting that Sethe characterizes Paul D, a man who endures enormous physical and psy- 
chological abuse, as a "singing man" at the outset of the novel (39; italics mine).

$\mathrm{T}$ raditionally, critics have either ignored song as a legitimate vehicle for establishing slave humanity or have limited their appraisal of song. Margaret Atwood notes how the theme of "tyrannical price" runs through Beloved but stops short of offering analysis of how slaves combat this tyranny with song and re-establish their humanity by singing about life (49). The slaves of Beloved have their humanity stripped from them throughout the novel, as cold statisticians like Schoolteacher attempt to calculate and record their "animal" tendencies above and beyond their "human" characteristics. In one such instance, Paul D learns "the dollar value of his weight, his strength, his heart, his brain, his penis, and his future" but responds by singing of the "bosses and masters and misses; of mules and dogs and the shamelessness of life" in order to confirm his humanity in the face of Schoolteacher's dehumanizing "value" equations $(226,108)$.

Robert O'Meally speaks at length of how Douglass's Narrative uses many "black sermonic devices to prepare the reader for [its] spiritual message," but fails to include song among the many "oratorical techniques" employed by Douglass $(196,201)$. Ironically, O'Meally concerns himself with the Narrative's sermonic quality and its relation to the black church while overlooking the fact that slave songs were "a testimony against slavery, and a prayer to God for deliverance from chains" (Douglass 58; italics mine). Ashraf Rushdy, in his article "Daughters Signifyin(g) History," uses Henry Louis Gates's definition of the "speakerly text" to situate Beloved in the African-American literary tradition. Rushdy argues that Beloved's narrative structure takes on "a dialogic form that is akin to music or black preaching" but never identifies the role of song in what he calls a "musical narrative" (56). Likewise, Marilyn Mobley notes how Beloved employs "the trope of memory" to make the slave experience more "accessible" to contemporary readers (357). She does not analyze, though, the crucial role that song plays in the characters' recollection of these horrifying memories. Mobley makes a brief and oblique analysis of song as she mentions the way the fragmented stories of each character "illustrate the call and response pattern of the African-American oral tradition," but she misses an opportunity to investigate the significance of these particular slave songs, offering as they do a distinctive cultural voice to the AfricanAmerican oral tradition. With Morrison's Beloved, we hear the spoken stories of Paul D, Sixo, Baby Suggs, and Sethe, and we are also aware of their songs that bear witness to the unspeakable horrors of slavery - those experiences whose shame transcends even the spoken word.

Whereas Douglass cites the importance of slave song for the first and last time at the end of his narrative's second chapter, Morrison establishes song as imperative to her characters' survival during nearly every chapter of Beloved. She includes the ability to sing among the barest and most rudimentary essentials of human existence early in the novel. At the house on Bluestone Road, if Paul D could "walk, eat, sleep, [and] sing," he could survive and "asked for no more" (41). Morrison also has Paul D sing while he mends "things he had broken the day before," in an effort to reconstruct his life after physical and emotional trials have shattered his identity at prison camp in Alfred, Georgia. Morrison emphasizes the importance of singing to Paul D's survival through her repeated acknowledgment at the outset of the novel that his songs "were too loud [and] had too much power for the little house chores he was engaged in" (40). In reality, Paul D's songs help him to reconstruct the broken pieces of his 
past life in Georgia more than to reset and glaze the table at 124 Bluestone Road.

The songs that Paul D sings upon his arrival at Sethe's house solidify both his autonomous and his collective participation in the black experience of slavery. On the individual level, Paul D "change[s] the words," "throwing in a line if one occur[s] to him" to establish an element of personal testimony in the song (40). In this crucial depiction of Paul D's singing, Morrison actually invokes the paradigm of song established by Frederick Douglass at the end of his narrative's second chapter:

The slaves selected to go to the Great House Farm, for the monthly allowance for themselves and their fellow-slaves, were peculiarly enthusiastic. While on their way, they would make the dense old woods, for many miles around, reverberate with their wild songs, revealing at once the highest joy and the deepest sadness. They would compose and sing as they went along, consulting neither time nor tune. The thought that came up, came out-if not in the word, in the sound;-and as frequently in one as in the other. They would sometimes sing the most pathetic sentiment in the most rapturous tone, and the most rapturous sentiment in the most pathetic tone. Into all of their songs they would manage to weave something of the Great House Farm. . . . They would sing, as a chorus, to words which to many would seem unmeaning jargon, but which, nevertheless, were full of meaning to themselves. (57)

In this way, slaves could bring their singular experiences to a song without relation to anyone else. On the other hand, song allows the slaves an opportunity to participate in the larger history of the black experience of shame, suffering, and endurance. If the thought did not come out in Paul D's individual word, it came out in the tone of the song. Therefore, by chang- ing the lines of the songs he sings at 124, Paul D establishes the autonomy of his particular experience while affirming his participation in and his endurance of the institution of slavery. It is interesting to note that, as her character Paul D accomplishes this, Morrison aligns Beloved within a tradition larger (and more important) than its Pulitzer Prize scope: the troping of song in American slave narratives. The specificity of Paul D's songs later in Beloved, though, exposes a primary difference between Morrison and Douglass. Douglass establishes the cru-
cial relationship between slaves and their songs, but Morrison probes deeper into the specifics of this relationship.

The cryptic nature of Paul D's character provides a particularly apposite site for Morrison to begin the process of extending Douglass's paradigm. Paul D's most gruesome experience occurs while under the supervision of Schoolteacher at Sweet Home, after Mr. Garner's death. Because of Schoolteacher's empirical (but no less brutal) division of "slaves" and "humans," and because he announces himself "with a coach full of paper" to record these discrepancies, Rafael Perez-Torres accurately suggests that Schoolteacher "becomes the speaking subject of slavery's discourse" (186). Paul D's dehumanizing experience with Schoolteacher is so physically and psychologically grueling that he has "never talked about it" and never "told a soul" (71). In one of the most solemn episodes of the novel, Paul D confides to Sethe that he could never speak to anyone about having his "tongue held down by iron" while looking at the roosters who had more freedom "to be and stay" than he (71-72). Nellie McKay characterizes Paul D's dilemma as the "wish to forget and the necessity to remember," but she stops short of identifying song as a vehicle for Paul D to accomplish both the forgetting and 
the remembering (12). That Paul D never told another human being about the Schoolteacher experience but "sang it sometimes" reveals the significance and the depth Morrison gives to song. In a world where relatives and friends suddenly vanish never to be seen again as a matter of everyday legal policy, Paul D cannot afford to speak to another person, but silence only embitters the internal anguish. Singing about the traumatic event empowers Paul D to confront his horrific past and make meaning of his dehumanizing experiences.

Paul D's horrific experience at prison camp in Georgia is an episode in which Morrison shows the power of song to combat even the worst and most dehumanizing despair. Song in Beloved not only "mends broken things," but it also gives Paul D the endurance to survive the chain gang in Georgia, where his humanity is aggressively violated. Paul D uses song to defend his humanity when it is denied most by "wooden boxes," "cage doors," "leg irons," and "bit[s] of foreskin" (107-08). As Morrison notes, "The songs from Georgia were flatheaded nails for pounding and pounding and pounding" (40). These songs give Paul $D$ the strength to brook eighty-six days of pounding rock and eighty-six nights while "reaching for air" (110). Most notably, as Paul D and other prisoners "danc[ed] two-step to the music of hand-forged iron," they sang to affirm their humanity while being worked and tied like animals:

They sang the women they knew; the children they had been; the animals they had tamed themselves or seen others tame. They sang of bosses and masters and misses; of mules and dogs and the shamelessness of life. They sang lovingly of graveyards and sisters long gone. Of pork in the woods; meal in the pan; fish on the line; cane, rain and rocking chairs. (108)

Morrison's inclusion of the specific topics of the slave songs from Georgia allows the reader to identify more closely with incredibly complex ideas of identity and worth during and after the chattel experience. She extends the concept of "weaving" from Douglass's description of the Great House Farm songs to include the specific song topics. The emphasis on the "animal" in these particular songs allows the slaves in Georgia's prison camp to establish themselves as human beings capable of acknowledging their humanity, even when their oppressors refuse to do the same. By singing about mules and dogs, pork and fish, relationships and pleasures, the slaves assert their humanity and defend themselves against the atrocities of the camp. Perhaps most importantly, Morrison's specific exploration of song reveals how "the men got through" chattel slavery and its horrifying reverberations even after emancipation (108).

The prison camp songs from Georgia bear a striking resemblance to those that Douglass includes in his 1845 Narrative because both place more emphasis on the sound than on the actual words. In Douglass's Narrative, for example, the slaves "compose and sing as they go along," placing meaning "if not in the word, in the sound." He even goes so far as to say that the words of his Great House Farm songs would appear "unmeaning" despite their profundity: Slaves "would sing, as a chorus, words which to many would seem unmeaning jargon, but which, nevertheless, were full of meaning to themselves" (57). Morrison extends the trope of this same "sound significance" in her Georgia songs as the prisoners "garbl[e] the words so that they [can] not be understood" while they "trick the words so that their syllables yield up other meanings" (108). Frederick Douglass establishes the context for this intangible, mutating element of the slave song when he enjoins his readers to go "deep in the pine woods" of Colonel Lloyd's plantation and to "analyze the sounds that pass through the chambers of his soul" as the slaves sing what many would call "unmeaning jargon" (57-58; italics mine). Morrison extends this belief and, therefore, has the pris- 
oners of Alfred, Georgia, sing songs with "garbled words" and "tricked syllables" to show the contemporary reader that the sound reflects more of the slaves' humanity than the words could ever reveal.

Sound alone registers the humanity of Beloved's slaves most incisively when Schoolteacher captures Paul A, Paul D, Sixo, and the Thirty-Mile Woman as they attempt to escape from slavery at Sweet Home. Caught and facing death by firing squad for their bold transgression, Sixo "grabs the mouth of the nearest pointing rifle" and "begins to sing" (225; italics mine). The white men find it impossible to shoot Sixo as he sings because the song locates "personhood" among slavery for a group of slave catchers who are conditioned to see only the "animals" of Schoolteacher's calculations. Slave catchers are trained to kill animals in leg irons with bits in their mouths - not human beings singing songs. Morrison acknowledges this discrepancy as the white men wait "with five guns trained on [Sixo] while they listen" to his song. Realizing that his song makes him far too human to shoot, one white man finally "hits Sixo in the head" to make him stop singing. Ironically, Schoolteacher changes his mind about wanting Sixo alive; his song must have convinced Schoolteacher "that he was too human ever to become a docile slave." Only after Sixo "is through with his song" do the white men see a slave and proceed to burn him alive (226).

Henry Bibb and Frederick Douglass refer to the institution of slavery as "the man destroying system" in their narratives, and Morrison tropes this idea of universal human degradation in Beloved. Morrison's revision of the traditional slave narrative comes, though, as she offers song as a response to the degradation.

Just as Captain Auld, Mrs. Auld, and $\mathrm{Mr}$. Covey are rendered less human by the effects of their association with slavery, so too are the white characters in Morrison's novel. As Houston A. Baker, Jr., points out, "Douglass is aware of American slav- ery's chattel principle, which equated slaves with livestock, and he is not reluctant to employ animal metaphors to capture the general inhumanity of the system" (76). Morrison shows how Schoolteacher and the slave catchers from Beloved act with the same barbarity and inhuman cruelty that epitomizes slave treatment during the chattel experience of the slave narrative. Because they are involved in what Douglass calls the "soul-killing" business of keeping slaves, Schoolteacher and the other white men of Beloved are reduced to subhuman behavior.

Morrison derives this principle of categorical human degradation from Douglass's Narrative. As Baker points out, slavery has a uniquely pernicious identity resulting from its power to degrade all it touches:

\begin{abstract}
Douglass's work is a chronicle of the "soul-killing" effect slavery had on both master and slave. Time and time again in the Narrative men's hopes for a better life are crushed: humans are whipped and slaughtered like animals; men and women are changed into maniacal and sadistic creatures by power; the strength of body and mind is destroyed by an avaricious and degrading system. (76)
\end{abstract}

Morrison's Beloved, however, does not simply chronicle the degradation set in motion by slavery; the novel also reveals how slaves use song to combat the inhuman protocol adopted by the oppressors. In this way, Morrison compels her audience to acknowledge the draconian punishment for an "offense" that needs no hyperbole - the act of burning alive a singing man who tries to escape a life of slavery.

Sixo establishes his humanity in front of the white men with his song, and the fact that Morrison does not record the words of this song is testimony to the higher significance of its sound. With Paul D's misunderstanding of the words to Sixo's song, Morrison shows the reader how the words to slave songs are belittled by the content of their sound. Her awareness of the precision with which Douglass locates the arresting inadequacy of these "would be" words is 
crucial to Morrison's project with sound in Beloved. Douglass reports early in his narrative: "I have sometimes thought that the mere hearing of those songs would do more to impress some minds with the horrible character of slavery, than the reading of whole volumes of philosophy on the subject could do" (57). Caught by

Schoolteacher and the slave catchers, Paul D thinks he should have sung "something loud and rolling to go with Sixo's tune, but the words put him off - he didn't understand the words" (227). By including this information, Morrison establishes the slave song as the ultimate projection of the human experience-one where words have no meaning and the sound carries every inch of sorrow and despair harbored inside the members of the enslaved community.

Melvin Dixon's article "Singing Swords: The Literary Legacy of Slavery" refers to these songs as "fundamental assessments of the collective human experience" (298). If this is valid, Paul D confirms his participation in the human experience as he remarks that his confusion "shouldn't have mattered because he understood the sound: hatred so loose it was juba" (227). The term juba comes from the name of the chief drummer in the jubilee songs who pounded out the rhythms on celebration days of black culture. Morrison's choice to include the juba dance in this section solidifies the connection between Sixo and Paul $\mathrm{D}$ and calls the reader to look at them not as slaves, but as human beings with a native culture.

Beyond this, Morrison's inclusion of the juba song at such a grave and desperate section of the novel reinforces the expansive range of emotion harbored within the "sorrow songs" that Douglass and W. E. B. Du Bois acknowledge in their own writings. In his Narrative, Douglass reports that the songs of Colonel Lloyd's slaves at the Great House Farm "reveal at once the highest joy and the deepest sadness" (57). Douglass's songs were sung in "complaint" for "souls boiling over in the bitterest anguish," but they were also sung as "a prayer to God for deliverance from chains." Sixo's song in front of the slave catchers certainly has within it some of this "complaint," but the reference to "juba" suggests more of what Du Bois, in The Souls of Black Folk, calls "faith in the ultimate justice of things" (213).

This work of enormous cultural and literary significance asserts that the common possession of a "soul" unites and defines humanity. Du Bois essentially extends Douglass's finding that "the souls of black folk" are revealed in the "sorrow songs." To Du Bois, the song of the black slave is "the most beautiful expression of the human experience born this side of the seas." Du Bois expands Douglass's belief that the songs recognize the deepest sadness and highest joy of a slave:

[The songs] tell of death and suffering
and unvoiced longing toward a truer
world, of misty wanderings and hid-
den ways. . . Through all the Sorrow
Songs there breathes a hope-a faith in
the ultimate justice of things. The
minor cadences of despair change
often to triumph and calm confidence.
Sometimes it is a faith in life, some-
times a faith in death, sometimes the
assurance of boundless justice in some
fair world beyond. But whichever it is,
the meaning is always clear: that some-
time somewhere, men will judge men
by their souls and not by their skins.
(207, 213-14)

Perhaps it is Sixo's song of hope-his "triumph and calm confidence" in the ultimate justice of things - that evokes such a barbaric and inhuman response from Schoolteacher and the slave catchers in Beloved when they burn him alive.

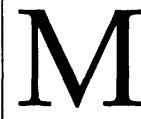
orrison also explores the complex relationship between song and humanity with her depiction of Beloved's unique origin - the events that surround Sethe's murder of her own child. She shifts song's function slightly to accommodate Sethe's unusual isolation from her own people. With Paul D and Sixo, Morrison's use 
of song defends the personhood of slaves, but with Sethe, song defines and affirms the neighborhood's decision to banish her. Immediately after murdering her daughter Beloved, Sethe exits through "a throng of black faces" but with no "cape of sound to hold and steady her on her way." The crucial absence of song highlights the fact that even Sethe's black neighbors regard her as inhuman for having murdered her own child. If Sethe had acted less barbarically, her personhood would have been recognized by the spectators and "the singing would have begun at once." Also, Morrison juxtaposes Sethe's seeming inhumanity with the "creatures" and "cannibals" that are mentioned on the pages immediately preceding Sethe's emergence from the house on Bluestone Road. In the same way that the "four horsemen" regard the slaves as having "gone wild," Morrison's choice to omit song in this episode shows how Sethe's own people believe her to be somehow less than human. The black neighbors wait until the cart carrying Sethe "head[s] west" before they make any sound at all (152). This conspicuous deficiency of song reveals the neighborhood consensus of Sethe's barbarity and ultimately signifies her formal banishment from the community.

On the other hand, Morrison uses the prevalence of song at the end of the novel to re-establish Sethe's humanity. After supporting a twenty-year policy of banishment from the neighborhood, the women in Sethe's community begin to question their harsh treatment and wonder about the "killed one" (Beloved) who has suddenly reappeared in the flesh. Ella, a deeply compassionate woman who had been "shared by husband and son" during puberty, finally convinces the other women that "rescue [from banishment i]s in order" for Sethe (256). Ella manages to persuade the others that "the idea of past errors taking control of the present" is an unjust burden on another human being and "so thirty women walk slowly, slowly toward 124." Morrison reinstates song here to reflect the change in the neighbor women's assessment of Sethe's humanity. The women sing in chorus and create a "music" that is "wide enough to knock the pods off chestnut trees" as Sethe stands in the doorway holding Beloved's hand (261). In one of the novel's most numinous images, the thirty women of the neighborhood join in song to create a sound so harmonious and powerful that it "br[eaks] the back of words." Karla Holloway misses a crucial opportunity to acknowledge this powerful element of song when she remarks that all the voices in the novel come together at times into "a tightened poetic chant" (72). Far beyond chanting, the "singing women" in this section confirm Sethe's re-instatement into the neighborhood, into motherhood, and, most importantly, into humanity. Ironically, the neighborhood women recognize their own inhuman lack of compassion in a way that the white characters of the novel never do.

Through this use of song in Beloved, Morrison forces the reader to identify with the humanity of her characters in the darkest era of American history, where bestiality preempts morality. Song affords the characters of her novel a form of personal testimony against the horrors of their past, and it strengthens them for the difficulties they come to accept as their future. Throughout the novel, Morrison shows how song not only has the power to "break the back" of words, but how it also destroys the numbers that the Schoolteachers of the world calculate so inhumanely. Just as the slaves" "savagery" assures Schoolteacher's "civilization," Beloved's victims use song to reclaim and affirm their personhood in an aggressively inhuman world. Each time Baby Suggs adjures Sethe to "lay down [her] sword," Morrison reveals how the characters pick up a song and use it as a shield to defend and affirm their humanity. Much as Sethe "talk[s] about love with a handsaw," Toni Morrison's Beloved speaks to its readers about humanity with a song (164). 
Atwood, Margaret. "Haunted by Their Nightmares." New York Times Book Review 13 Sep. 1987: 1. 49-50.

Baker, Houston A, Jr. Long Black Song: Essays in Black American Literature and Culture. Charlottesville: UP of Virginia, 1972.

Dixon, Melvin. "Singing Swords: The Literary Legacy of Slavery." The Slave's Narrative. Ed. Charles Davis and Henry Louis Gates, Jr. New York: Oxford UP, 1985. 298-318.

Douglass, Frederick. Narrative of the Life of Frederick Douglass, An American Slave. 1845. New York: Penguin, 1986.

Du Bois, W. E. B. The Souls of Black Folk. 1903. New York: Penguin, 1989.

Holloway, Karla. "Beloved: A Spiritual." Callaloo 13 (Summer 1990): 516-25.

McKay, Nellie, ed. Toni Morrison's Beloved: A Casebook. New York: Oxford UP, 1999.

Mobley, Marilyn Sanders. "A Different Remembering: Memory, History, and Meaning in Beloved." Toni Morrison: Critical Perspectives Past and Present. Ed. Henry Louis Gates, Jr., and K. A. Appiah. New York: Amistad, 1993. 357-65.

Morrison, Toni. Beloved. 1987. New York: Penguin, 1988.

O'Meally, Robert. "Frederick Douglass' 1845 Narrative: The Text Was Meant to be Preached." AfroAmerican Literature: The Reconstruction of Instruction. Ed. Dexter Fisher. New York: MLA, 1979. 192-211.

Perez-Torres. "Between Presence and Absence: Beloved, Postmodernism, and Blackness." McKay 179-202.

Rushdy, Ashraf. "Daughters Signifyin(g) History: The Example of Toni Morrison's Beloved." American Literature 64 (1992): 567-97.

\section{Call for Papers Sterling Plumpp}

Submissions are invited for a proposed volume, "'Cause Chance Gives Me Commands": Writing in Conversation with Sterling D. Plumpp. Michael A. Antonucci and Duriel Harris, co-editors, seek creative works and original essays (20-25 pages in length) which contribute to the discussion of Plumpp's body of work and related subjects. Send one-page, single-spaced abstracts by MAY 1, 2003 to:

\section{"The Sterling Project" \\ C/O Michael Antonucci}

Department of English (M/C 162)

601 S. Morgan St.

Chicago, IL 60607 